\title{
Some thoughts about the value of an OECD international assessment framework for early childhood services in Aotearoa New Zealand
}

Contemporary Issues in Early Childhood 2016, Vol. 17(4) 450-454

(c) The Author(s) 2016 Reprints and permissions: sagepub.co.uk/journalsPermissions.nav DOI: $10.1177 /|463949| 16680705$

cie.sagepub.com

\section{Margaret Carr}

University of Waikato, New Zealand

\section{Linda Mitchell}

University of Waikato, New Zealand

\section{Lesley Rameka}

University of Waikato, New Zealand'

To fairly and truly judge what a person can do, you need to know how the talent (skill, knowledge) you are assessing is situated in - placed within - the lived social practices of the person as well as his or her interpretations of those practices. ... many a standardized test can be perfectly 'scientific' and useless at the same time; in a worst case scenario, it can be disastrous. (Gee, 2007: 364)

We were alerted to this warning from James Gee because it is from a chapter that reflects on assessment from a sociocultural-situated perspective. The New Zealand early childhood education curriculum, Te Wharriki, also takes this perspective and, in this short article, we argue that the use of Organisation for Economic Co-operation and Development (OECD) standardized tests to evaluate our early childhood education sector, while it may be perfectly 'scientific', could be disastrous for Te Whäriki. We have comments made by Tilly Reedy and Tamati Reedy (two of the lead writers for the 1996 curriculum) at a 2013 OECD meeting in Wellington in mind:

Te Whāriki is a curriculum which is child-centred and learning-oriented - ko te whakamana i te tamaiti ki te ako te pütake o tênei marautanga. The basic principle that underpins Te Whāriki is 'to empower the child to learn'. Te Whāriki is the first curriculum of its kind for Aotearoa-New Zealand. After 200 years of educational history, Māori was, for the first time, being given the opportunity to influence a new curriculum that would touch the minds of future New Zealanders. (Reedy and Reedy, 2013) 
The following are some of the implications of implementing the OECD outcomes framework that might threaten the foundations of Te Whāriki - and contribute to Gee's 'worst case scenario': (1) New Zealand's early childhood education curriculum takes a sociocultural perspective on learning; the OECD measures provide a 'one-world' view in an internationally standardized context; (2) an unwarranted international reputation can be established; (3) low-income communities may be especially vulnerable; (4) follow-on interventions, teaching to the OECD measures, are likely to encourage a pedagogy of compliance; and (5) we have already established more important issues to focus on.

\section{New Zealand's early childhood education curriculum takes a sociocultural perspective on learning; the OECD measures provide a 'one-world' view in an internationally standardized context}

In 2003, the OECD organized the first policy workshop on the early childhood curriculum. A report from the workshop summarized the distinctive features of Te Whäriki:

Rather than employing a one-world view of human development emptied of context, or articulating a curriculum with the subject-based learning areas and essential skills of the school, Te Whãriki chooses a socio-cultural approach to curriculum based on a desire to nurture learning dispositions, promote bi-culturalism and to reflect the realities of the young children in the services. (Organisation for Economic Co-operation and Development, 2004: 17)

Gee (2007: 366) elaborates on this sociocultural approach to outline three interlinked elements in a sociocultural-situated view of language, learning and the mind: an acculturated, socialized, embodied actor, within a situation, coordinating him- or herself with other people and objects, tools or technologies (mediating devices). He adds that no element in this triad can be defined or dealt with in isolation, because 'each simultaneously and continuously transforms the others throughout the action or thought'. This sociocultural view of the learner has been described as the 'person-plus' (Perkins, 1993); a 'person-plus' is an appropriate unit for assessment in a socioculturally framed curriculum. We do not need here to rehearse the history and nature of the socioculturalecological and bicultural platform for the early childhood curriculum in New Zealand (for details see Lee et al., 2013; Ministry of Education, 1996; Nuttall, 2012). A section on 'Principles of Te Whäriki and assessment' is set out on page 30 of the curriculum document. That page includes the comment: 'Assessing or observing children should take place in the same contexts of meaningful activities and relationships that have provided the focus for the holistic curriculum' (Ministry of Education, 1996: 30).

The following indicative outcomes in Te Whäriki illustrate some of these activities and relationships (in the interest of brevity, we have included one outcome from each of the goals in three strands: contribution, communication and exploration). ${ }^{2}$ These describe children who (1) are confident that their family background is viewed positively; have developed a perception of themselves as capable of acquiring new interests and abilities; and have an appreciation of the ways in which they can make contributions to groups; (2) have developed: responsive and reciprocal turntaking skills; language skills in a range of real, play and problem-solving contexts; experience with creating stories and symbols; and an ability to be creative and expressive through a variety of activities; and (3) have developed: the knowledge that trying things out, exploration and curiosity are important and valued ways of learning; strategies for actively exploring and making sense of 
the world (using their bodies, tools and materials); a perception of themselves as explorers who ask questions and make discoveries; and the ability to enquire, research, explore and modify their own working theories about the natural, social, physical and material worlds.

This list illustrates just a few of the outcomes in the philosophically complex and educationally rich sociocultural Te Whäriki. They are situated in - placed within - the lived social and cultural practices of the children, as well as their interpretations of those practices. To lose them as the front frame for teaching and learning would be disastrous.

\section{An unwarranted international reputation can be established}

Since the development of Te Whāriki, we have mostly been concerned with formative assessments that attend to learning in context and highlight acculturated learner selves. These local narrative assessments and their portfolios enable continuity of learning and relationships with families and local communities to be appreciated and developed. Pamela Moss (2008: 239) reminds us that: 'We need to acknowledge and study the way in which assessment offers learners identities and positions'. Summative achievement assessments can also powerfully offer learner identities and positions; sometimes these are negative, as an article by Diane Reay and Dylan Wiliam (1999) entitled "I'll be a nothing"' eloquently illustrates. Experience with the Programme for International Student Assessment and other international evaluation programmes reminds us that these identity and reputation issues for learners apply equally at a national level. Interventions, with the OECD measures as the focus, are likely to follow.

\section{Low-income communities may be especially vulnerable}

Who will be successful on the OECD context-free measures? Our guess is: (1) children from resource-rich communities of families who include test-like and context-free tasks, activity books and activities in their social capital, and (2) children who have been coached to succeed in these tasks. New Zealand is characterized by a widening gap between the rich and the poor, and the inequity of education outcomes that parallels this gap has been extensively documented (Wilkinson and Pickett, 2009). The possibility arises that teachers and pedagogy in low-income 'non-dominant' communities will take the blame for an evaluation of Aotearoa's early years education that is dangerously off-target. Follow-on interventions, equally off-target, might follow.

\section{Follow-on interventions, teaching to the OECD measures, are likely to encourage a pedagogy of compliance}

Stuart Shanker (2012), writing on classroom strategies for self-regulation (one of the OECD's probable domains), has warned of the danger of teaching the apparent 'signs' of self-regulation via demands for compliance, instead of the more complex notion of encouraging the disposition of self-regulation through a number of domains (biological, emotional, cognitive, social and prosocial) with social relationships as a key lever.

A feature of the early childhood education landscape in New Zealand, relevant to this danger, is the strong presence of for-profit private providers. In a sector dominated by private providers, if the OECD data is available for individual centres, the market will provide a strong incentive to 'teach to the test' (Stobart, 2008), with a competition agenda ('We teach the international OECD programme') and a compliance mindset. 


\section{We have already established more important issues to focus on}

When the government of the day becomes anxious about the costs of funding early childhood, it may be tempted to call on the apparent precision of numbers to prescribe and measure context-free and curriculum-free internationally developed and validated outcomes over time - and to use those numbers as a benchmark. But the Aotearoa New Zealand early childhood sociocultural and bicultural curriculum, recently endorsed by the Advisory Group for Early Learning, ${ }^{3}$ has established a set of priorities for teaching and learning that are different from most of the other OECD countries. Furthermore, research analysis and informed commentary about the drivers of good early childhood education and the purpose and consequences of assessment practices have moved away from these past simple solutions and measures, as two recent publications commissioned by the New Zealand Ministry of Education have documented (Carr et al., 2014; Mitchell et al., 2014).

What should we focus on for improvement? International comparisons or local, situated indicators that include implications for facilitating educational environments? As the early childhood sector in New Zealand continues the implementation of Te Wharriki in the 21st century, it is our view that we would be better placed to build on the work that has already begun to develop broad outcomes for 'Strengthening the Learning and Realising Potential' with reference to the five sociocultural strands of learning outcomes in Te Whäriki (Learning Outcomes Working Group of the MoE Research Policy Forum, 2011), and to keep in mind the principles, strands and goals in the Te Whäriki document itself.

\section{Funding}

The author(s) received no financial support for the research, authorship, and/or publication of this article.

\section{Notes}

1. The authors are in the Early Years Research Centre at the University of Waikato. This article was written to contribute to the New Zealand Ministry of Education's Early Childhood Education Research Policy Advisory Forum discussions on 6 September 2016. The Early Childhood Education Research Policy Forum Group includes university academics and leaders in the early childhood education field; it meets with Ministry personnel three or four times a year for discussions of mutual interest. At the September meeting, the group sought information about the International Early Learning Study and expressed its dismay at New Zealand's possible involvement.

2. Currently, the Ministry of Education is preparing an 'update' of Te Whäriki; this will not change the principles, strands or goals, which set out the sociocultural frame.

3. A group of around 10 leaders in the early childhood field in New Zealand, chaired by Joce Nuttall from Australia. This group held a number of meetings in 2015; it endorsed Te Whāriki as the national early childhood curriculum and made recommendations for the future.

\section{References}

Carr M, Davis K and Cowie B (2014) Continuity of early learning: Learning progress and outcomes in the early years. Report on the literature scan to the Ministry of Education. Wellington, New Zealand: Ministry of Education.

Gee JP (2007) Reflections on assessment from a sociocultural-situated perspective. Yearbook of the National Society for the Study of Education 106(1): 362-375.

Learning Outcomes Working Group of the MoE Research Policy Forum (2011) Strengthening the learning in ECE: A framework. Unpublished paper. Wellington, New Zealand: Ministry of Education.

Lee W, Carr M, Soutar B, et al. (2013) Understanding Te Whäriki. London: Routledge.

Ministry of Education (1996) Te Whāriki. Wellington, New Zealand: Learning Media. 
Mitchell L, Cowie B, Clarkin-Phillips J, et al. (2014) Case studies of assessment practice. Examples from continuity of early learning: Learning progress and outcomes in the early years. Wellington, New Zealand: Ministry of Education.

Moss P (2008) Sociocultural implications for assessment I: Classroom assessment. In: Moss P, Pullin DC, Gee JP, et al. (eds) Assessment, Equity and Opportunity to Learn. Cambridge: Cambridge University Press, pp. 222-258.

Nuttall J (2012) Weaving Te Whäriki: Aotearoa's Early Childhood Curriculum Document in Theory and in Practice. Wellington, New Zealand: NZCER Press.

Organisation for Economic Co-operation and Development (OECD) (2004) Starting Strong: Curricula and Pedagogies in Early Childhood Education and Care - Five Curriculum Outlines. Paris: OECD.

Perkins D (1993) Person-plus: A distributed view of thinking and learning. In: Salomon G (ed.) Distributed Cognitions: Psychological and Educational Considerations. Cambridge: Cambridge University Press, pp. 88-110.

Reay D and Wiliam D (1999) 'I'll be a nothing': Structure, agency and the construction of identity through assessment. British Educational Research Journal 25(3): 343-354.

Reedy T and Reedy T (2013) Te Whāriki: A tapestry of life. In: Curriculum implementation in ECEC: Te Whāriki in international perspective, keynote address, Wellington, New Zealand, 9 December 2013.

Shanker S (2012) Calm, Alert and Learning: Classroom Strategies for Self-Regulation. Toronto, ON, Canada: Pearson Canada.

Stobart G (2008) Testing Times: The Uses and Abuses of Assessment. London: Routledge.

Wilkinson R and Pickett K (2009) The Spirit Level: Why Equality Is Better for Everyone. London: Penguin.

\section{Author biographies}

Margaret Carr is professor of education in the Wilf Malcolm Institute of Educational Research at the University of Waikato. She has researched and published widely on issues of curriculum implementation and formative assessment.

Linda Mitchell is associate professor in the Faculty of Education at the University of Waikato in Aotearoa New Zealand. She is the director of the Early Years Research Centre in the Wilf Malcolm Institute of Educational Research. Linda teaches in the undergraduate and graduate education programme and researches widely, nationally and internationally, on issues of curriculum implementation and early years education.

Ko Tararua te maunga, Ko Ohau te awa, Ko Tainui te waka, Ko Ngāti Tukorehe me Ngāti Raukawa nga iwi. Lesley is a senior lecturer at the Faculty of Education, University of Waikato in Tauranga, where she teaches and researches in early childhood and Māori education programmes and projects. 